\title{
Gateball Sports and the Forming of Students' Characters
}

\author{
Mesnan*, M. Irfan, Rosmaini Hasibuan \\ Lecturer in Universitas Negeri Medan, Indonesia
}

*Corresponding Author: Mesnan, Lecturer in Universitas Negeri Medan, Indonesia

\begin{abstract}
Gateball sports is one of the new sports developed in Indonesia, especially North Sumatera. The Faculty of Sports Sciences at Medan State University began to develop sports in 2013. As a new sport, research needs to be conducted on various aspects related to this sport. Therefore this study aims to describe the relationship between gateball sports and student character formation. The data of this study are 20 a student taking a gateball course. This study uses an approach qualitative naturalistic which means that research has an actual background as a direct source data and researchers are key instruments. Research is done by doing observation during the lecture period and giving questionnaires. The results of the study show that affective aspects are very prominent due to gateball sports. And this thing impact on lecture activities that occur in students, namely: (1) attendance, (2) activity in learning, (3) responsibility, (4) discipline, (5) caring towards friends, (6) taking time to read, (7) prioritizing discussion, (8) trusteeship, (9) has mature maturity, and (10) has a communication style polite. Thus it can be concluded that gateball sports can form aspects affective in students.
\end{abstract}

Keywords: Gateball, Students' Character, Affective Aspects, Sports, Learning

\section{INTRODUCTION}

Medan State University (Unimed) as a university in North Sumatra have responsibility in producing productive human resources and have knowledge in answering all challenges and changes that occur in in the midst of society. The University's motto as The Character Building University guided by improving human resources as a manifestation of quality related to the system of education, training, and assessment of equality of learning outcomes (learning outcomes) nationally to produce national human resources quality and productive. The Faculty of Sports Science (FIK) is one of the education providers the Unimed strategy plan in developing research and realizing it University goals. FIK Study Topics in conducting research cover two fields among them first is education such as the study of the application of learning, curriculum, pedagogy, and recreation. Second is the non-education field which includes health studies, psychology, technology, sports engineering, and study of facilities and infrastructure. Both studies must be related to sports or in accordance with the field of expertise and concentration of the faculty.

Sports studies include elements of the body in the form of objects and work in the form of motion theory (motor control) is the study of nerve function factors that affect human motion. The nervous system is an important part in producing human motion, because nerve cells stimulate muscles to produce human motion (Rahyubi, 2014: 207). The process of improving exercise through a scientific approach, especially the principles of exercise, regularly and planned so as to enhance the ability and readiness of sportsmen (Hare in Ambarukmin et al. 2007: 1).

Thomson (1993: 61) in Ambarukmin, et al (2007: 1) explained that "a systematic process to improve the fitness of athletes in accordance with the chosen sport". The conclusion of the statement is that doing sports systematically will lead to the quality of sports actors in the form of movement skills, physical fitness and energy capacity. Sport becomes a special and important view to be applied in society and education, especially universities in instilling attitudes or self-affections in the learning process. The aim is to improve the degree of physical and spiritual health.

The sport that is currently developing in North Sumatra is gateball sports. Gateball sports was discovered by Eiji Suzuki in 1947 in the small town of Memuro, Hokkaido, Japan. The area that first appeared in gateball in Indonesia was Bali in 1995. Ball played in groups using a stick on a grassy open field or a closed field with artificial grass without any obstacles. 
Gateball is a sport that is carried out by relying on accuracy, so that it requires deep concentration so that the goals to be achieved in the game can be obtained. Football is played in teams and the game pattern of each team is arranged by the captain (team leader). All team members must obey the pattern that will be applied to the team captain so that the game strategy can turn off the opponent's game.

Each player must help each other and try to fight against each other in a way that touches, then a shot that can be rolled into a favorable direction for the team. The ball is the appearance of the own beating stepped on the foot, and a famous ball that is affixed to sparking. This sport emphasizes teamwork, the use of tactics and playing strategies, coupled with the skills of using the sticks of players.

Motion in gateball sports related to body conditions, namely physical and psychological effects create a person's self-affection to be able to play well. Affection or affective (deep feelings) are positive or negative and related to certain objects will always be accompanied by feelings of pleasure or displeasure, sympathetic or antipathy (Husdarta, 2010: 24). Affective in the learning process will provide awareness about the importance of understanding the science explicitly and straightforwardly in accordance with the demands of teaching that have been taught (Shah, 2013: 52). Understanding of science will have an effect on the application of teachings and adaptation to the environment in using knowledge that is possessed appropriately.

Gateball sports have not been well known to the public, especially North Sumatra. The study of gateball sports is still not extensive and needs to be developed so that gateball sports can be accepted by the public or sportsmen. The results of the study of gateball are one of the ways to develop gateball sports and will influence the scientific development and popularity of gateball sports, and can be used as a superior sport in an area to improve achievement, influence on the psychic, and competitiveness between regions.

The existence of gateball sports is a big challenge for sports observers, especially the FIK Unimed institution as an institution that should be responsible for maintaining its capacity and existence in the field of sports, meaning that any sports developments that occur in North Sumatrera should first be studied and developed by FIK Unimed. Gateball sports in North Sumatra are also not an obligation of FIK Unimed to develop it, but if FIK Unimed is too late to explore and develop it compared to other institutions, then FIK Unimed will be assessed as slow and not following the development of sports that occur in North Sumatra.

FIK Unimed on this occasion still has the opportunity to develop gateball sports in North Sumatra. The effort to conduct research and studies on gateball sports is one of the efforts to make FIK Unimed as a sports mecca in North Sumatra. This study also reveals the benefits and impact of learning on attitude As for the purpose of this study was to determine how the relationship between gateball learning and the formation of student characters.

\section{Gateball}

Eiji Suzuki was the originator of gateball sports in the city of Hokkaido, Japan in 1947. Gateball is a modification of a Croquet game from France that uses a bat and ball stick. Gateball is a sport played by two teams and each team is five people. The sports a gateball in the play is carried out on a grassy, flat-sanded field.

Gateball sports began to enter Indonesia since the arrival of Japanese tourists to Balipada in 1994. Japanese tourists tour and play gateball as a recreation and entertainment. Balinese people are interested and enthusiastic about playing gateball and begin to routinely harvest it. The gateball exercise routine played by Balinese people was seen by Public Works Minister Joko Kirmanto during a visit to Bali and the minister was interested in developing gateball in Indonesia.

Gateball sports became known when the Indonesian Gateball Association (Pergatsi) was formed and was a member of the Indonesian Community Recreation Sports Forum (Formi). For the world level, there is also a gateball Union parent organization. Gateball can be enjoyed by men and women of all generations, therefore gateball is also called a barrier-free sport (Prasetyo, 2012: 1).

Gateball is a type of sports by using a bat and played by 2 (two) teams consisting of 5 players for each team facing each other. Playing balls are shown in flat grass fields, no obstacles, and rectangular shapes. The target of each player is to enter the ball through 3 gates in a row. And finally the goals are installed in the middle of the field during the most playing time of 30 minutes. 
This sport is played sequentially based on the ball number, in the field there are 3 gates and in the middle there are 1 pole. Players can enter the game and play 2 shots or if possible about the alternator / opponent so they can make $2 x$ hits. Each entry is gotten 1 point and hit pole 2 points, each player can collect a maximum of 5 points.

Gateball is played by two teams, the red team and the red Team white team holding an odd ball $(1,3,5,7,9)$ while the white team holds an even ball $(2,4,6,8,10)$. The red team hits the ball first and then the white team follows the order of the ball numbers.

The ball is hit through 3 goals (goal 1 to 3 ) and finishes the game if it has touched the goals. Winners are determined by the total number of scores obtained during 30 minutes of game time.

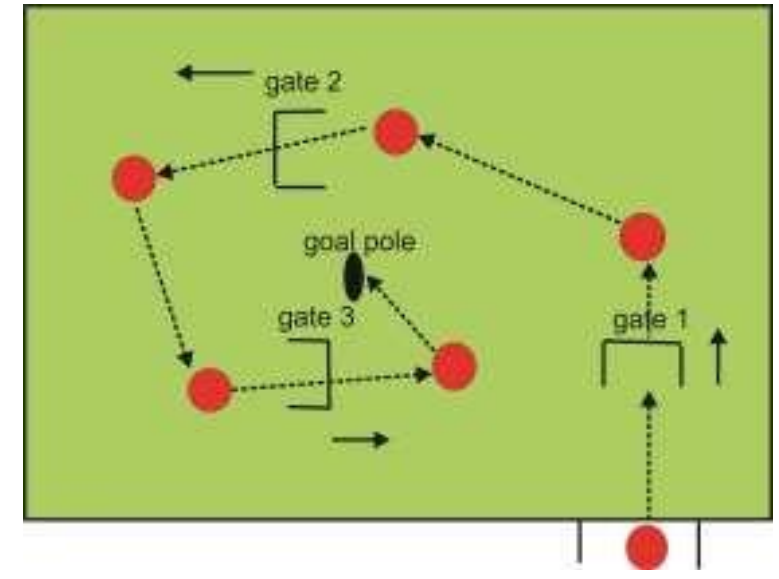

Fig2.1. How to play Gateball

\section{AFFECTIVE ASPECTS OF LEARNING}

Education in terms of psychology is an effort to develop resources human power through the process of interpersonal relationships in the environment. Educational process causes students to depend on the lesson in class its perception of teaching teachers and the classroom environment.

Learning theory in the learning process can be understood as a general principle or a collection of interconnected principles, and is an explanation of a number of facts and discoveries relating to learning events. Affective behavior is behavior involving diversity of feelings such as fear, anger, sadness, joy, disappointment, happy, hate, anxiety, and so on. Such behavior cannot be separated from the influence of learning experience or exercise training (Shah, 2013: 125).

The learning process in the operant conditioning theory is behavioristic in a more meaningful sense emphasizes the emergence of tangible and tangible physical behavior. According to the law of law operant conditioning is if the emergence of behavior is accompanied by a stimulus stimulus, then the power of behavior will increase (Shah, 2013: 100). According to Krathwohl, 1964 (in Solikin, 2014: 11) in his book Taxomony of Educational Objectives: Affective Domain, as quoted by Roestiyah N.K, the affective domain has a level that is: acceptance, response, respects, self-organization (organizing), and value characterization.

Acceptance, is the attitude of one's awareness or sensitivity to symptoms, conditions, conditions or a problem. Someone chooses positive attention to certain symptoms if they have an awareness of symptoms, conditions, or objects which exists. Responding or responding is intended by the willingness to actively participate in certain activities such as the willingness to complete assignments on time, willpower to help others, the willingness to follow orders, and so on. Respectful, this goal relates to the willingness to give an assessment or trust in symptoms or a particular object. Respect consists of acceptance a value with certain beliefs, such as accepting the existence of freedom orequality between men and women; prioritizing a value like having belief in the truth of a particular teaching; and commitment to the truth he believed in activity. Self-organizing (organizing), which is the goal relating to the development of values into certain organizational systems, including relationship between values and the priority level of those values. This goal consists of conceptualizing values, which is to understand abstract elements of a value that has been owned with values that come later; and organizing a value system, namely developing a consistent and rounded system of interconnected values including loose values. Characterization of values, namely related 
goals by conducting a synthesis and internalization of the value system with assessment deeply, so that the values it builds are made into views (philosophy) of life, and used as a guideline in acting and behaving.

The concept of affective learning refers to the potential of students both from the aspect of copyright related to the brain and intelligence, aspects of taste related to emotions and feelings, and intentions or desires or skills that are more physical. Reflection Affective can be translated into several behaviors that arise in the learning process namely attendance, activeness, responsibility, discipline, caring about learning, and ethics in the learning process, and have an impact on behavior outside of learning.

\section{Gateball AND AfFective Sports Relations}

Gateball is a sport that is done by relying on ability accuracy, so that requires deep concentration so that the target is desired achieved. This ability is called attention, which means that there is a process scanning, focusing, maintaining attention (sustaning in focus) and changing the focus of attention from one activity to activity then known as shifting in focus (Puspitawati, Hapsari, and Suryaratri, 2012: 111). Accuracy is obtained from concentration through sensory nerve responses to the description of the opponent's game and match strategy, and the inner motor nerves take the right action, this is the main capital and an absolute requirement for achieving a glorious achievement carried out by an individual's self-confidence (Husdarta, 2010: 92).

Gateball sports are sports that are played in teams and emphasize response to cooperation, using tactics and strategies so as to create self-regulation towards the team in achieving goals. Each gateball team is governed by the captain (team leader) and all team members must respond and follow the pattern the captain will apply team towards the game strategy used. Teamwork is an effort to realize social psychology and self response as a predisposition in increasing the motivation of the offender exercise in groups / teams towards the efforts of its members to achieve achievement (Husdarta, 2010: 96).

The theory of operant conditioning is a number of behaviors or a response that has the same effect on the immediate environment. Someone's habits who makes a good response as well as following the team's instructions creating a condition of self that is ready to carry out activities without being preceded by a stimulus but rather the effects caused by reinforcement or habits (Shah, 2013: 98).

\section{RESEARCH METHODOLOGY}

This study uses a qualitative naturalistic approach which means research have an actual background as a direct source of data and the researcher is a key instrument. The problems discussed aim to describe a situation or phenomenon which is based on a complex order, a holistic picture, arranged with words, report detailed views of informants or research sources and carried out in natural or natural settings (Bogdan and Bilken, 2008: 4-5 in Emzir, 2012: 2-3).

The procedure for conducting this research was conducted to find sports studies gateball on affective aspects is a series of activities:

- Studying gateball sports through sports techniques and game techniques.

- Conducting Group Discution (FGD) Forums with the research team

- Formulate the results of the FGD relating to research studies

- Analyzing the affective aspects of gateball athletes in the activities lecture / learning

- Conduct Group Discution Forum (FGD) with the research team

- Formulate the results of the FGD relating to research studies

- Evaluate the study and conclude the results of the study of the affective aspects of the sport gateball

6. RESUlts

Research on gateball sports studies on the affective aspects of students done by observing the game of gateball sports, analysis, collection data, evaluation, and conclusions. The research team with gateball coaches and National athletes gateball discusses gateball sports at the Medan State University (Unimed). The results of the discussion obtained were: 
"Gateball Sports is a new sport in Unimed since 2017 introduced by the Lecturer in the Faculty of Sports Sciences (FIK) Drs Mesnan, M.Kes. Gateball has not experienced significant development and has not had many interested ones especially in the Unimed environment. The Unimed FIK Faculty consists of lecturers and Students try to develop gateball sports by activating the gateball club Unimed and did exercises every day, and played an active role in every good activity regional and national level.

The development of Unimed gateball sports began to be inaugurated with the establishment gateball club through the Dean Decree assigning to several lecturers and students to play a role in developing gateball sports. The development of gateball sports can be felt by conducting research conducted by Unimed students who also act as gateball and athlete athletes the lecturers who shared the goal of developing gateball sports. Results the research aims to raise the name of the gateball to be better known and become reference to gateball sports fans in developing science in the field of sports.

Research conducted by the Unimed gateball club Counselor Lecturer with the title "study gateball exercise on the affective aspects of Sports Science Faculty students " aims to provide a specific and scientific view to all readers especially FIK Unimed students to be interested in participating in gateball sports forming character or personality in accordance with the Unimed Caharacter pillar.

Gateball sports on the affective aspects have the opportunity to become a means of formation character culture in each personality in the Unimed environment with sports activities namely gateball sports. Such statements are based on the research conducted the lecturers through the Expertise Lecturer Group (KDBK) with the concentration of study gateball sports. "

The activity process of the research team was accompanied by trainers and gateball athletes to discuss or Forum Group Discussion (FGD). The results of the FGD are the composition of assessment instruments will be filled by student respondents and lecturers of lectures according to class and majors. Instruments are arranged to obtain data on conditions that occur during the process lectures or learning of the Faculty of Sports Sciences (FIK) students as athletes gateball sports.

The research instrument is a questionnaire in the form of a rubric, filled with giving a sign checklist $(\sqrt{ })$ in the information column according to the activities carried out by the student. Questionnaire given to colleagues / friends, and lecturers who teach the gateball athlete. Total Lecturer respondents numbered 10 people and 100 students consisting of students PJKR, PKO, and IKOR according to the direction of each gateball athlete.

The athlete's data obtained from Unimed's gateball club totaled 20 people from 14 men and 6 women. Research to study gateball sports against affective aspects include all gateball athletes starting from semester $1,3,7$, and 9 .

The results of filling out the questionnaire obtained information that

Table6.1. Questionnaire Filling Result

\begin{tabular}{|c|l|c|c|}
\hline No & \multicolumn{1}{|c|}{ Activities } & Respondents & $\%$ \\
\hline & Present at the lecture (80\%) & 108 & $98 \%$ \\
\hline & Actively ask or interact during lectures & 99 & $90 \%$ \\
\hline & Be responsible for the lecture assignment & 106 & $96 \%$ \\
\hline & Come on time (discipline) & 110 & $100 \%$ \\
\hline & Response and help friends if they have learning difficulties & 100 & $91 \%$ \\
\hline & Take time to read / study, discuss, and go to the library outside of lecture hours & 57 & $52 \%$ \\
\hline & Prioritizing discussion rather than arguing, when problems occur in class & 105 & $95 \%$ \\
\hline & $\begin{array}{l}\text { Able to keep promises (if promised), or complete work / tasks according to } \\
\text { the time agreement }\end{array}$ & 102 & $93 \%$ \\
\hline & Able to be a mediator and help resolve each lecture / class problem & 110 & $100 \%$ \\
\hline & Have a polite communication style & 98 & $89 \%$ \\
\hline \multicolumn{2}{|c|}{ Total } & 995 & \\
\hline
\end{tabular}

The calculation obtained based on filling out the questionnaire is $90.5 \%$. The calculation results shows that $90.5 \%$ is a category "Very Good", and has that meaning the lecture process of gateball 
athletes at FIK Unimed has a very good influence on affective aspects. The affective aspects found in the gateball athlete are the help of pillar character which characterizes and prioritizes Medan State University for realizing students who are personality and examples of students with character well.

The next gateball exercise study was carried out by the team's FGD researcher and team of gateball experts to obtain appropriate information regarding activities gateball sports against students. The FGD results are formulated in a description and described as follows:

- Gateball is a sport that prioritizes the ability to control feeling, namely the system work between emotional mind-strength (regulating the explosive power of the arm muscles and emotional).

- Gateball is a sport that does not require high expressive motion, however requires high psychological performance and thought to be able to move accuracy of punches, targets, game strategies, and emotional management.

- Gateball is a psychic sport, because of the whole process of playing gateball moreinclined to use psychological aspects, namely calmness, patience, and team discipline in regulating game patterns.

The results of the gateball exercise study have been obtained both as a result of filling out the questionnaire, and the results of the FGD. The connection between the data thus provides information that in the study of gateball exercise has an influence on the affective aspects. Aspect affective is influenced by the element of motion and the activity of gateball sports that are more prominent on the psychic such as (1) control feeling that is the system of work between mind-strength, (2) performance psychic and high mindedness to be able to move accuracy against blows, goals, game strategies, and emotional management, (3) calm, patience, and discipline team in regulating game patterns.

The affective aspects that stand out due to the game of gateball have an impact on lecture activities that occur in students, namely: (1) attendance, (2) activity in learning, (3) responsible, (4) discipline, (5) caring for friends, (6) take the time to read, (7) prioritize discussion, (8) trust, (9) have mature maturity, and (10) having a polite communication style. Appearance the attitude of the gateball student can have an impact especially in developing the new sport as a character-based sport and can be used as a superior sports at Medan State University.

\section{CONCLUSION}

Temporary conclusions obtained based on the research process carried out are:

- Gateball sports is a sport that uses aspects of thinking and psychic thoughwhich affect the affective aspect. Affective aspects are influenced by elements of motion and the activity in gateball sports is more prominent in psychic students.

- Gateball sports can have a good impact on the process learning / lectures, because gateball sports can shape attitudes and good personality in students. The impact of student affective can influences the development of gateball sports as a sports based character.

\section{REFERENCES}

[1] Ambarita, Biner dan Wanapri Pangaribuan. (2011). Pendidikan Karakter ( Konsep dan Implementasi ). Medan: Universitas Negeri Medan

[2] Ambarukmin, D.H., Pasurney, P., Sidik, D.Z., Irianto, D.P., Dewanti, R.A., Sunyoto,

[3] Sulistiyanto, D., \&amp; Harahap, M.Y. 2007. Pelatihan Pelatih Kondisi Fisik Level I. Jakarta: Asdep Pengembangan Tenaga dan Pembina Keolahragaan.

[4] Emzir. 2012. Metodologi Penelitian Kualitatif Analisis Data. Jakarta: Rajawali

[5] Husdarta, H.J.S. 2010. Psikologi Olahraga. Bandung : Alfabeta

[6] Mulyaarja dan Hastuti, T.A. 2015. Peningkatan Keaktifan Aspek Afektif Siswa dalam Pembelajaran Gerak Dasar Lompat Tinggi dengan Metode Permainan Siswa Kelas IV SD Negeri Banyurade Gamping Sleman. JurnalPendidikan Jasmani Indonesia.11(2): 111-117

[7] Prasetyo, Y. 2012. Olahraga Gateball Bagi Usia Lanjut. Jurnal Medikora. 8(2): 1-15 Puspitawati, I., Hapsari, I.I. \&amp; Suryaratri, R.D. 2012. Psikologi Faal. Bandung “PT Remaja Rosda Karya

[8] Rahyubi, H. 2014. Teori-Teori Belajar dan Aplikasi Pembelajaran Motorik. Bandung: Nusa Media

[9] Solikin, M. 2014. Strategi Pembelajaran Afektif untuk Pembentukkan Karakter Bertanggungjawab bagi Santri. Yogyakarta : Universitas Islam Negeri Sunan Kalijaga

International Journal of Sports and Physical Education (IJSPE)

Page $\mid 24$ 
[10] Sudijono A. (2009). Evaluasi Pendidikan. Jakarta, P.T. Raja Grafindo Persada.

[11] Syah, M. 2013. Psikologi Belajar. Jakarta : P.T. Raja Grafindo Persada

Citation: Mesnan, et.al. “Gateball Sports and the Forming of Students' Characters " International Journal of Sports and Physical Education (IJSPE), vol 5, no.1, 2019, pp. 19-25. doi: http://dx.doi.org/ 10.20431/24546380.0501004.

Copyright: (C) 2019 Authors. This is an open-access article distributed under the terms of the Creative Commons Attribution License, which permits unrestricted use, distribution, and reproduction in any medium, provided the original author and source are credited. 